Hilger ; Foucault apparatus for measuring the velocity of light; Ladd polariscope with large collection of crystals ; two extra large Nicols ; anemograph, King's barograph, and standard barometer by Casella ; resistance coils, large electro-magnet and a great variety of electric and physical apparatus, including one of Prof. Rowland's magnificent gratings. Among the smaller telescopes are :

$$
\begin{aligned}
& \text { 12-inch reflector by Browning-With, } \\
& 6 \text {-inch refractor by Dallmeyer, } \\
& 6 \text { " " " " " } \\
& 4 \text { " " Cooke and Sons, } \\
& 3 \text { " " " }
\end{aligned}
$$

All the foregoing are equatorially mounted with clockwork, and there is an object-glass prism by Merz, which fits either of the 6-inch telescopes.

A 4 -inch reversible transit by Cooke and Sons, with stand for both the meridian and prime vertical, is mounted in a detached hut.

A Zöllner's astrophotometer, a 12-inch altazimuth by Simms, a variety of theodolites, sextants, reflecting

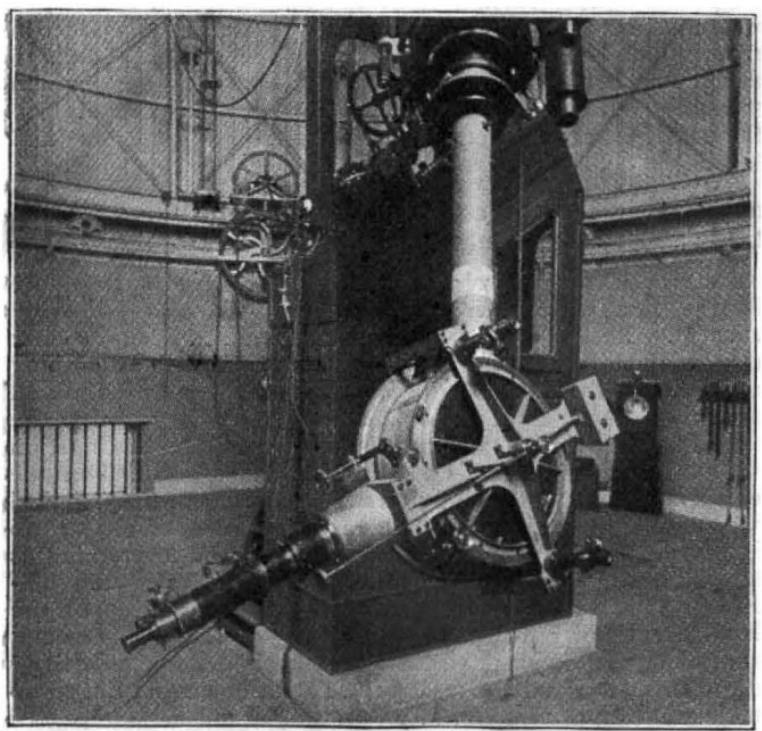

Fig. 2.-Stellar Spectrescope, by T. Cooke and Sons, attached to the i5-inch Dunecht Refractor. (The divided circle is 18 inches in diameter.)

circles, cameras, spectroscopes, and prisms from $4 \frac{1}{2}$ inches downwards, complete the outfit for work at the observatory and on expeditions.

A word must be said about the clocks. Two of these, the Dunecht sidereal clock by Frodsham, and the excellent Makdougall-Brisbane clock by Dent, from Calton Hill, are mounted in the base of the pier of the larger tower, shut in by thick double doors stuffed with "slagwool." This guarantees a nearly uniform temperature for both clocks, while the Brisbane timekeeper has the further advantage of being subjected to a uniform barometric pressure of 25 inches maintained inside a cast-iron case. This latter part of the arrangement has been most efficiently carried out by Messrs. Jas. Ritchie and Son, of Edinburgh. Automatic signals from this chamber serve to rate the mean time clock, which is kept to Greenwich time, and transmits currents to Edinburgh and Dundee for regulating the time signals.

The 8:6-inch transit circle by Troughton and Simms, formerly at Dunecht, is mounted in a detached double iron house 80 feet west of the observatory, with which it is connected by a covered way. It has two finelydivided circles--one of them movable. North and south of the instrument, but in the same room, are two 6-inch collimators, which can be pointed on each other through a hole in the $17 \frac{1}{4}$-inch central cube of the telescope. The opening in the roof is 39 inches broad.

The great 4-barrelled chronograph by Cooke, from Dunecht, capable of recording six hours' continuous observations on each barrel, is mounted in the base of the west tower. It is supplemented by a small 3-pricker fillet chronograph by Fuess, of Berlin. Both instruments can be worked from six places in the observatory, and with either of the sidereal clocks. The clocks can also be compared automatically on the chronograph, or audibly by a sounder.

In the south wing the principal room is the library, 24 feet by 34 feet 6 inches, and 20 feet in height, which contains the astronomical library collected by Lord Crawford at Dunecht, comprising about i 5,000 volumes. Divided amongst the computing rooms are the books removed from Calton Hill.

The observatory and instruments are lighted by electricity, generated by a 7-horse Crossley gas engine, charging 53 large storage cells.

Within the boundary wall of the observatory stand the house of the Astronomer Royal for Scotland, two semidetached villas for assistants, and a gate-lodge for the care-taker and messenger.

The transit circle and reflector have only just been mounted, but the large refractor has been in use since last autumn, and in spite of the very unfavourable weather a considerable number of observations of comets have been secured with it. The provisionally-adopted coordinates of the transit house are: Latitude $+55^{\circ} 55^{\prime} 28^{\prime \prime} \circ$. Longitude $12 \mathrm{~m} .44^{\circ} 2 \mathrm{~s}$. west of Greenwich. It is not likely that these will have to be materially altered.

\section{THE PLACE OF SCIENCE IN EDUCATION.}

THE Bishop of London should know something about education. He has been the Principal of a Training C llege, an Inspector of Schools, and Head Master of Rugby School, and he has written in a broad spirit on educational matters. No wonder, then, he modestly confessed at the London Diocesan Conference last week, that "he happened to know a good deal about education." There is one branch of knowledge, however, which he thinks should be cut off from the educational tree nurtured in elementary schools, and that is the branch of science. "He had very often felt," he said, referring to the Education Bill, "that it had been a very great evil that we insisted upon instructing little children in elementary schools in a great many scientific subjects, and he should not have been at all sorry if all these scientific subjects were got rid of entirely, and it had been left to the managers, and to the teachers under the managers, to introduce other subjects which would be more suitable." And, later on, he remarked: "Teaching of an advanced character might very well be permitted in some schools, but in regard to all these scientific schools, and the apparatus connected with them, the sooner they were got rid of the better."

Evidently Dr. Temple is moved by the oppression which schools suffer from science, and he desires to emancipate them. But to any one familiar with the facts as to scientific instruction in this and other countries, and the beneficial results which proceed from it, Dr. Temple's strongly-expressed desire will appear astounding. The schools in which science is successfully taught (and we count success not so much by examinational results as by the training of the mind and eye and hand, and the development of the spirit of inquiry), invariably contain the most intelligent scholars; the towns or districts which possess properly organised and equipped science schools contain

No. 1383 , vol. 5.3 l 
the largest proportion of skilled and inventive workmen. It is in the elementary schools that the foundations of natural knowledge should be laid, and there the faculty of observation should be trained to feed the mind; yet these are the schools which the Bishop of London would shut out from the light of science. For many years men interested in scientific education have been striving for a fuller recognition of science in our educational system, and not without a certain measure of success. But now comes Dr. "Temple and says in spirit, if not in the exact words, "Away with all these abominations. Purge the elementary schools of everything scientific, and substitute dogmas and subjects more fitted to the stations of life in which it has pleased God to call the scholars.". It is difficult to believe that sentiments so antagonistic to scientific study should have been uttered towards the end of the nineteenth century, and by one who is regarded as a friend of educational progress. But it is gratifying to know that Dr. Temple is only expressing the desire of a few ecclesiastics when he declares for the expulsion of science from elementary education. All who have the good of the country at heart, and who know the immense industrial harvest which Germany has reaped, and is reaping, as the result of generous provision for science in education, will regret that a man in the exalted position of the Bishop of London should have been the mouth-piece of words so narrow in their signification as those we have quoted-words which really lead one to think that he has not yet grasped the difference between "education" and "instruction." As it happens, we have received during the past week a copy of the address delivered by the Right Hon. A. J. Mundella to the members of the Association of Technical Institutions at their last annual general meeting, and we subjoin a few extracts from it, in the hope that they will lead Dr. Temple and his friends to a better appreciation of the value of scientific education.

Germany and Switzerland have, for more than half a century, been perfecting their educational system. They have trained up two generations in the most efficient and best manner that these two nations can afford, and they have profited very largely by it.

Now, to my mind, it is astonishing that this should be the case with such comparatively poor nations, because they have made their institutions accessible to every citizen, even to the poorest. There has been a lavishness amounting almost to extravagance in their expenditure. A few years ago I was in Berlin, and I was talking to my old friend Prof. Hofmann, who was then at the head of that great Charlottenburg Institution, the first technical institution in Europe. I remarked to him that I had been through various institutions in Germany and Switzerland the previous year, and it seemed to me that they were rather over-producing scientific men, the supply was in excess of the demand. "It is true," he said, "that we are producing more than we can absorb. We have a plethora of scientific men; only this year in my own department, two hundred Doctors of Science have taken degrees in the universities of Germany. But you must bear one thing in mind; we have the export trade entirely to ourselves."

"Go where you will throughout the world, you will find the German chemist at the head of every industry into which chemical science enters. I was in America, making a journey through the States some two or three years ago, and wherever I went I was entertained by German chemists and German scientific men, many of whom were old students of mine. They were at the head of every industry to which scientific knowledge is applicable, chemical works, gas works, breweries, whatever it was a German was at the head of it." And he said, "You know that pays. When a German scientific man wants plant or machinery, and that plant is manufactured in Germany, he goes to Germany for it, he does not go to England." That is quite true. The position that the German chemist, the German scientist, the German technologist has taken throughout the world, has done much to assist German industry.

NO. I 383 , VOL. 53$]$
The extent to which Germany and Switzerland have profited by technical teaching, is hardly realised by the English people. We are beginning to learn it; Switzerland, we are told by Sir O. Adams, in his excellent book on the "Swiss Confederation," exports a greater amount of manufactures per head for her population, than any other country in the world. It seems almost incredible that it should be so, that a country without natural resources, without iron, without coal, without a port or a navigable river, should nevertheless have a greater export of manufactures than any other nation in the world, not excepting England. But it is true, gentlemen, and she owes it entirely to her education. ...

Look at Germany. What has Germany gained by her sacrifices? I have been reading the most recent consular reports from that country: they furnish a mass of testimony in proof of the advantages she is reaping from her persistency in an enlightened educational policy. Hamburg trades very largely with English-speaking countries. Years ago she made English a compulsory subject in her common schools. She has been unsparing in expenditure for the equipment of her citizens, and she is reaping her reward. If, thirty years ago, any one had ventured to prophesy that in I895 the tonnage of sea-going ships touching at Hamburg would exceed that of Liverpool, we should have laughed him to scorn ; but this "striking fact" was announced to us a few days ago. Our Consul at Stettin reports that the educational authorities of that city propose to devote four hours a week to the study of English in the common schools. What would be said in England if a School Board on the north-east coast was to make German a compulsory subject?

After stating a number of remarkable instances of the effects that foreign competition is having upon British trade and employment, Mr. Mundella continued :-

Let us ask ourselves why it is that our rivals are so successful ? In the first place their elementary schools are thoroughly efficient. The teaching staff consists of trained adults, 90 per cent. of them being men. The scholars attend with astonishing regularity, and the school-life is sufficiently long to permit of their mastering the full curriculum of the school. When at the age of fourteen (in Switzerland it is often fifteen) the continuation school perfects, and adds to, the knowledge acquired in the elementary school. Then follows the high school, the technical school, and the university. There is no waste of effort; no overlapping; everything is co-ordinated; and everything is accessible to "the youth of pregnant parts." Fees are sufficiently low, or scholarships are provided, to admit of the humblest scholar of promise securing a thoroughly sound education. In Switzerland the high schools are free as well as the elementary, and the fees at the Polytechnicum at Ziirich do not exceed $£ 4$ per annum. ..

Well, gentlemen, what is our position? We are still the first industrial nation in the world. What is our educational position? Are we first? Comparisons are odious. They are in this case; one hardly likes to make them. ${ }^{1}$ Having regard to our wealth, the magnitude of our industries and of our commerce, the vast interests that we have in our keeping, we ought to be the first. Why are we behind, and what ought we to do to obtain supremacy in educa. tion as well as maintain it in industry? Well, you must begin at the bottom, you must improve the elementary education. We, to a great extent, owe the present condition of things to the early leaving of school, to the half-time system, to the low standards which prevail, especially in the country districts, where the fourth standard is the standard of total exemption. Think of the numbers that enter factories at eleven years of age. Think how few stay at school until they are thirteen or fourteen. It is true we have done excellent work under Forster's Act. We should take shame to ourselves that we have not done more. but we have done as much as the country would allow us; and we have been always, I think, in advance of the opinion of the country.

We trust that these extracts from Mr. Mundella's address will bring the Bishop of London to a better understanding of the place and value of science in education.

I Dr. Virchow visited England four or five years ago, and on his return to Berlin he reported, "England is a century before us in sanitation, and a century behind us in education." 